\title{
Szüléssel kapcsolatos rítusok és tabuk a hagyományos és a modern Koreában
}

A születés világszerte a különböző népek körében, azok fejlettségi szintjétől függetlenül az egyik legfontosabb esemény egy család vagy akár egy közösség életében. A koreai hagyományos társadalom ${ }^{1}$ tekintetében sem volt ez másképp - olyan eseményként tartották számon, amely komoly előkészületekkel és szabályok betartásával járt. Ilyen keret jellemezte gyakorlatilag mindegyik átmeneti rítust. Az átmeneti rítus, azaz a rite de passage egy olyan ,ceremoniális esemény, amely mindegyik történelmileg ismert társadalomban létezik, az egyik társadalmi vagy vallási állapotból a másikba való átlépést jelzi". ${ }^{2}$ Az erről a témáról megjelent egyik legfontosabb mü Arnold van Gennep kiadványa, amelyben a kutató terepmunkája során gyüjtött ismereteit rendszerezve, csoportosítva mutatja be a különböző beavatási, átmeneti rítusokat. Ö alkotta meg és definiálta az ,átmeneti rítus" fogalmát. ${ }^{3}$

A születéssel kapcsolatos rítusokra a koreai nyelvben föleg a sansok 산속 産俗 és a ch'ulsaengŭirye 출생의례 出生儀禮 terminológia használatos. Ezzel a témával a koreai kutatók, főleg a néprajz területén, az 1900-as évek középső évtizedeiben sokat foglalkoztak, ennek köszönhetően több ilyen gyüjtés beszámolójaként megjelent publikáció is elérhető. Fontosnak tartom a téma vizsgálatát, hiszen a tanulmány további bekezdéseiben bemutatott részletek a XXI. századi Koreában már csak részben léteznek, az általam használt források is több évtizeddel ezelőtt kivitelezett kutatások eredményei, és az említett jelenségek többségére már csak az idősebb generáció emlékszik, a modernizáció és a mindennapi élet változásainak következtében ezek a szokások és a hozzájuk tartozó szabályok eltünőben vannak. Történelmi források keve-

Ez alatt kb. az 1950-es évek elejéig tartó időszakot értem, a gazdasági fejlődés, modernizáció, urbanizáció és az ezek miatt bekövetkező társadalmi változások megkezdődése elöttig.

2 „Rite of passage”, Encyclopaedia Britannica (online).

3 A mü pontos adatai: Arnold van Gennep: Les Rites de Passage. E. Norry, 1909. 
sebb segítséget nyújtanak, hiszen a korábbi évszázadok feljegyzései a magasabb társadalmi osztály életére koncentráltak, a köznép mindennapjairól nem igazán maradt írásos emlék.

A szüléshez kapcsolható rítusokat funkciójuk alapján csoportosítani lehet, ezek következők: a kijasok 기자속 祈子俗 - a fogantatásért, sanjŏnsok 산전속 産前俗 - a születés előttiek, sanhusok 산후속 産後俗 - a születés utániak, illetve a yugasok 육아속 育兒俗 - a gyerekneveléssel kapcsolatosak. A tanulmány főleg az első három csoport definiálására, az ezekhez kapcsolódó rítusrendszer, szabályok és tilalmak bemutatására vállalkozik. Majd zárásképpen kitér arra, hogy milyen formában maradtak meg ezek a jelenlegi Koreában, melyek tüntek el közülük, és mi helyettesíti őket napjainkban.

A téma pontos körbejárásához elengedhetetlen a koreai terminológiák feltüntetése, a koreai és a kínai írásjegyekkel együtt. A képekkel is jól bemutatható témákhoz pedig a melléklet tartalmazza az illusztrációt. A tanulmány lábjegyzetében a források címét magyar fordításban jelölöm meg, az eredeti címek a Felhasznált irodalomban ezek alapján olvashatók, kivéve az enciklopédiából ${ }^{4}$ származó szócikkeket.

\section{A koreai népi hiedelemvilág mint háttér}

A koreai történelem elmúlt évszázadaiban számos különböző ideológia volt hatással a félsziget berendezkedésére és lakóira. Ugyanakkor az első államalakulatok idején ezek még nem intézményes vallásokat jelentettek, hanem hiedelemrendszerek és filozófiák összetett együttélését. A legtöbb kínai közvetítéssel érkezhetett Koreába, ezek meghonosodása elött is voltak azonban a koreai népnek elképzelései a világ müködéséről. Kiemelhető közülük például az animizmus, ${ }^{5}$ amely a koreaiaknál annyiban ismerhető fel, hogy rendszeresen tartottak hálaadó vagy könyörgő szertartásokat a ház körül, a ház helyiségein belül, a termöföldeken, a természetben, de abban is hittek, hogy bizonyos

4 Korea hagyományos társadalmának vizsgálatakor egyik legegyértelmübb és leghasznosabb forrás a Koreai néprajzi nagyenciklopédia, amely egy kétkötetes, koreai nyelven íródott részletes és pontos mü. A mai szótárakban meg sem található, korábbi társadalomhoz, annak életéhez kötődő szókészlet bőséges gyüjteménye.

5 A latin anima 'lélek' szóból származik, lényege a természeti népek ama felfogása, hogy minden lélekkel bír, nemcsak az élőlények, hanem a természeti világ, az égitestek, a használati tárgyak is. Magyar Néprajzi Lexikon. 
tárgyakban szellemlények élnek, vagy azokból születnek. Nem meglepő tehát, hogy felfogásuk szerint az élet egyik legfontosabb eseményét, a születést is egy természetfeletti erő vigyázza és irányítja, és ennek befolyásolásához a közösség tagjai szertartásokat, imádságokat, áldozatokat alkalmaznak.

Ez a gyakorlat egészülhetett ki aztán a közösség vallási életéért felelös sámán tevékenységével, hiszen a Koreai-félszigeten is, már a buddhizmus megjelenése előtt jóval, nagy szerepet töltött be a sámánizmus. Míg az uralkodó családok általában egy-egy vallás vagy ideológia követői voltak, a nép sok esetben a helyi hiedelmekkel szinkretizmusban élő sámánizmust gyakorolta. ${ }^{6}$

\section{A fogantatás előtt}

A születési rítusok bemutatását valójában a fogantatás előtti időszaktól kell elkezdeni, mert a hagyományos társadalomban fontosnak tartották, hogy a fogantatás bekövetkezését különböző szokásokkal segítsék elő. Ezek és a további szokások is regionálisan eltérő változatokkal rendelkeztek. A gyermekáldás érdekében elvégzett rítusokra általánosan jellemző volt, hogy maga a gyermekre vágyó lány vagy az ő édesanyja végezte el a rítust, bizonyos esetekben sámánt vagy bábát is bevontak. Általában esti vagy éjszakai órákban alkalmazták, nappal, világosban sokkal ritkábban került ezekre sor. A helyszínt főleg a felkeresendő szellemlény vagy istenség ,lakhelye” határozta meg, néha otthon, a háztartáson belül chipch'isŏng 집치성, de több esetben inkább a természetben, hegyen sanch'isŏng 산치성 vagy esetleg buddhista templomban chŏlch'isŏng 절치성 tartották. ${ }^{7}$ A térség nyelvezetétől függően kaphatott különböző elnevezéseket is, magát a rítust alapvetően a ch'isŏngŭl ollida 치성을 올리다 kifejezéssel említették. Ha forrásvíz mellett tartották, akkor abból a vízből inni is kellett. Valamint a szertartás közben a meghajlás iránya is meghatározott volt. A jó irányt ,ártó szellem nélküli irány” son ŏmnŭn panghyang 손 없는 방향 névvel illették. A szertartáshoz természetesen hozzátartozott valamilyen felajánlás is. Ezek különböző növények, termések, például rizs, gesztenye, jujube, datolyaszilva, alma, körte, hínár, rizssütemény, ehető hegyi növények, só is lehetett, ezek kívül akár pénz vagy gyertya is. Több közülük kifejezetten a gyermekáldásra vagy a gyermek nemére való kívánságot hordoz,

\footnotetext{
6 A koreai sámánizmus jelenségéröl ld. Birtalan 2002: 13-20, valamint Hoppál 2005.

7 „Ch'isŏnggija”, Folkency Encyclopedia of Korean Folk Culture (online).
} 
a gesztenye, jujube és datolyaszilva a fiúgyermek iránti vágyat, a hínárleves és a tiszta víz pedig a leánygyermek iránti vágyat szimbolizálja. A szertartás megtartásának számtalan módja lehet: verbális vagy nonverbális módszer. A testről minden negativitást, tisztátalanságot el kell távolítani, ezért sokszor többszöri fürdés is megelőzhette. Az imádságot meghajlás is kísérte. A szertartáshoz használt eszközök között lehetett több olyan is, amit a szomszédságból, egy olyan háztartásból loptak el, ahol éppen gyermek született. Egy így szerzett edénybe például aztán hét marék rizst, hét pirospaprikát, hét csomó tengeri hínárt és hét ív papírt soji 소지 燒紙 $^{8}$ tettek. $^{9}$ (A hetes szám és annak szorzatai a koreaiaknál is fontos jelentőséggel bírtak, lásd alább is.)

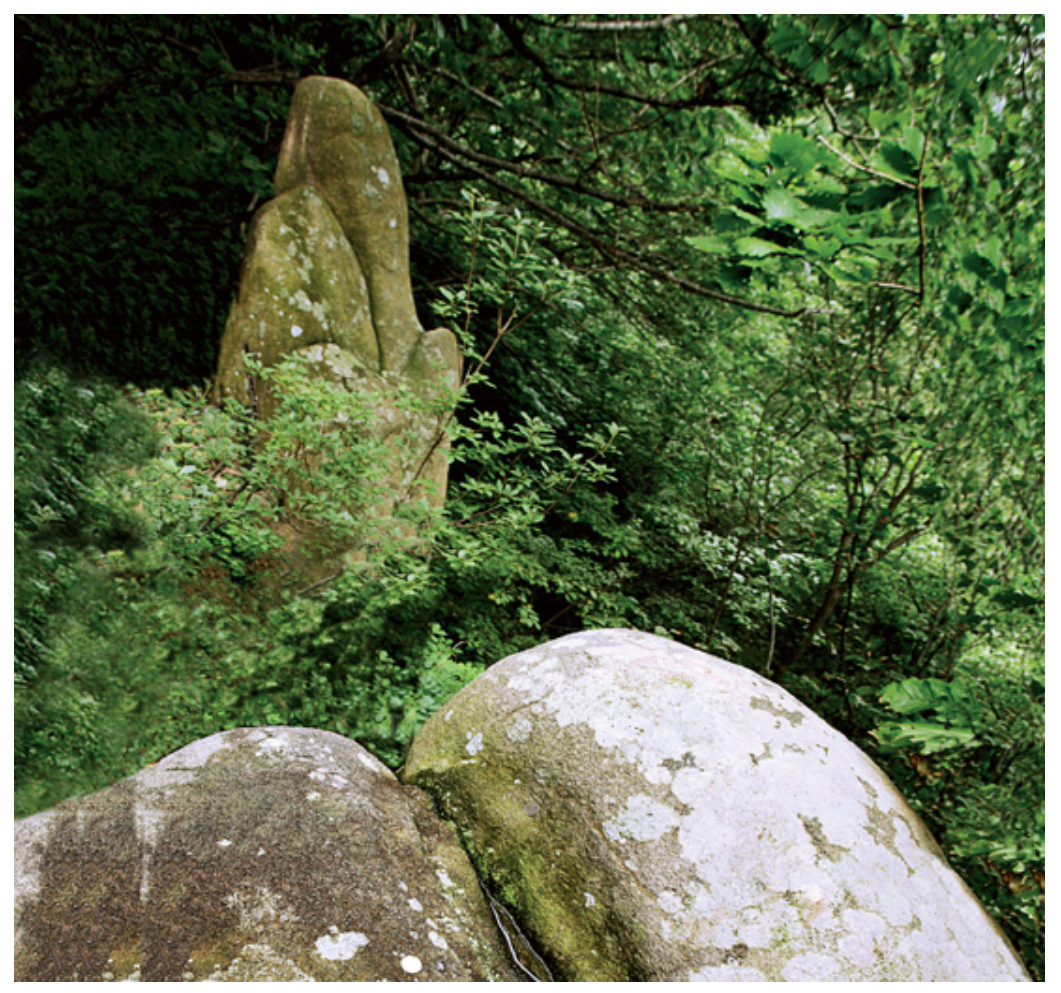

1. kép. Nöi és férfi nemi szerv alakú szikla

8 Meghatározott méretüre vágott hanji papír, amelyet általában sámánszertartások alkalmával megtisztítás érdekében elégetve sokat használnak („Soji”, Encyclopaedia of Korean Culture, AKS online)

9 Pae 1981: 81-86. 


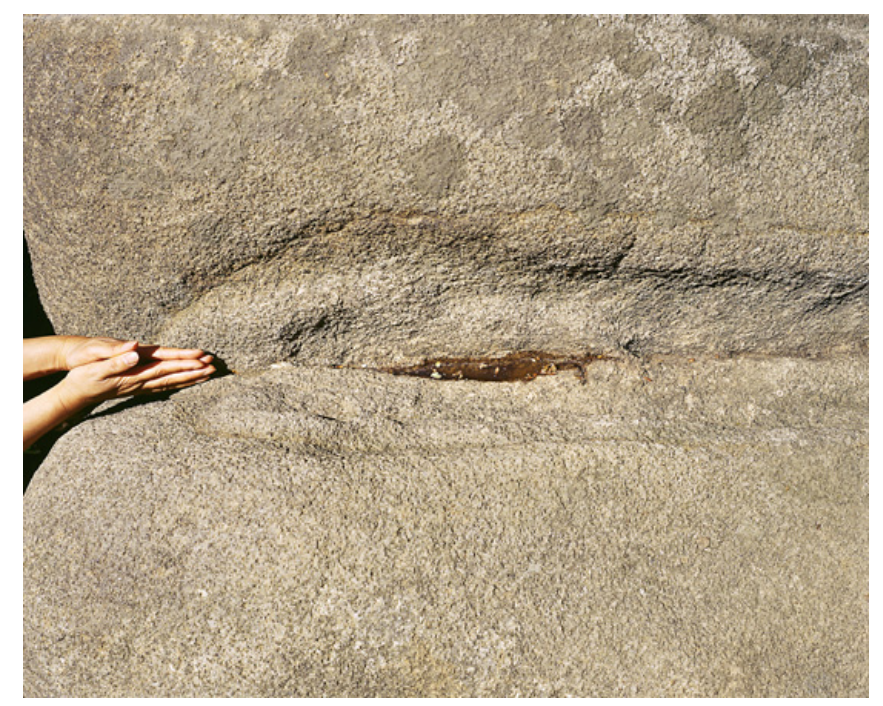

2. kép. Nöi nemi szervre hasonlitó szikla a Sammak buddhista kolostorban

A Koreai-félszigeten is létezett fallikus kultusz. A leendő anyák vagy nagymamák több alkalommal a természetben található, nemi szervekre ${ }^{10}$ emlékeztető sziklákat kijaam 기자암 祈子岩 vagy egyéb természeti képződményeket kerestek fel. Ezen kívül más formájú, de tekintélyes méretü köveket is olyan helynek hittek, ahol istenség lakozhat. Például Ullungdo közelében a tengerszélen van egy nagy kő, amelyet a tengeri viszontagságok már lyukasra formáztak, és úgy tartják, ha a szertartás alatt is arra csapnak a hullámok, és átfolyik rajta a víz, akkor a fogantatás is sikeres lesz, és fiú fog születni. Az ilyen helyek felkeresésekor akár a résztvevők maguk is visznek kisebb szobrokat a helyszínre. ${ }^{11}$ Máig az egyik leghíresebb a Szöul egyik külső hegyén, a Kwanak-hegyen elhelyezkedő Sammak kolostor, amelyben egy helyen férfi- és női szervre hasonlító szikla is van (1. és 2. kép). Évszázadok óta úgy tartják, hogy ezek megérintése garantálja a könnyü szülést. Már a korai történelmi királyságok idején is ismerték, neves buddhista szerzetesek is ismertették a helyet a Shilla- és a Koryŏ-időszak alatt is. ${ }^{12}$ A kövek felkeresésének szokása szájról szájra terjedő történetekben is fennmaradt.

\footnotetext{
10 Férfiszerv esetében ezt namgŭnsŏknak 남근석 男根石, női esetében yŏgŭnsŏknak 여근석 女根石 hívták.

11 Pae 1981: 81-86.

12 „Adŭl nak'irŭl pinŭn p'ungsong - kijasok”, Buddhista újság (online, Dongguk University).
} 
어느 마을에 금실 좋은 부부가 살았는데, 자식이 없었다. "씨받이라도 들이자"며 시어머니는 난리였다. 날로 수척해지는 며느리에게 어느 날 꿈에 할머니가 나타났다. "삼막사에가 성석을 문지르면서 소원을 빌어보라”는 말을 남기고 사라졌다. 다음날부터 부부는 바위를 찾아가 움막을 짓고 치성을 드렸다. 그 후 신통하게도 부인은 아들을 낳았고 자손도 번창했다. 그로부터 삼막사 성석은 자식 낳기를 바라는 기원처로 알려졌다. ${ }^{13}$

Egy faluban nagyon harmonikusan élt egy házaspár, de mégsem született gyerekük. Az anyós már szidta őket, hogy ha mást nem, egy béranyával próbálkozzanak. A napról napra csak lesoványodó menye azonban álmot látott, amelyben egy öregasszony azt mondta neki, hogy menjen a Sammak templomba, fogja meg a sziklát, és mondja el a kívánságát. A következő naptól a házaspár letelepedett a sziklák mellé, és fogantatási szertartásokat mutattak be. Ezután mintegy varázsütésre, a feleség fiút szült, és sorra születtek az utódaik. ${ }^{14}$

Egyedül ebben a buddhista templomban fordul tehát elö, hogy egy helyen megtalálható a férfi és a női nemi szervet formázó szikla is, ráadásul egymás mellett, valamint a születést elősegítő Buddhák kőbe vésett ábrázolása is felfedezhető. A középső Buddhának alig van már orra, mert a legenda szerint, ha az onnan lekapart kőport valaki vízzel keverve megissza, akkor könnyen fogan fiúgyermeke. ${ }^{15}$

A mezőgazdasági közösségekben ezen kívül létezik a fa kiházasítása elnevezésű szokás is, amikor az y alakban növő faágak közé kavicsot tesznek (namushijipponaegi 나무시집보내기) (3. kép).

Ezeket a szokásokat kija shinang 기자 신앙 祈子信仰 vagy kijaŭiryeként 기자의 례 祈子儀禮 találhatjuk meg a szöveghagyományban, amely főleg a Chosŏn-kori (1392-1897), a köznép körében elterjedt szokásokat foglalja össze (4. kép). A Chosŏn-királyságra jellemző konfucianizmusnak is köszönhetően általánosan elterjedt a fiúgyermek preferenciája nemcsak a magasabb társadalmi osztályokban, hanem az alacsonyabb rangú családoknál is.

\footnotetext{
Ch'oe 2015.

14 Saját fordítás.

15 Ch'oe 2015.
} 


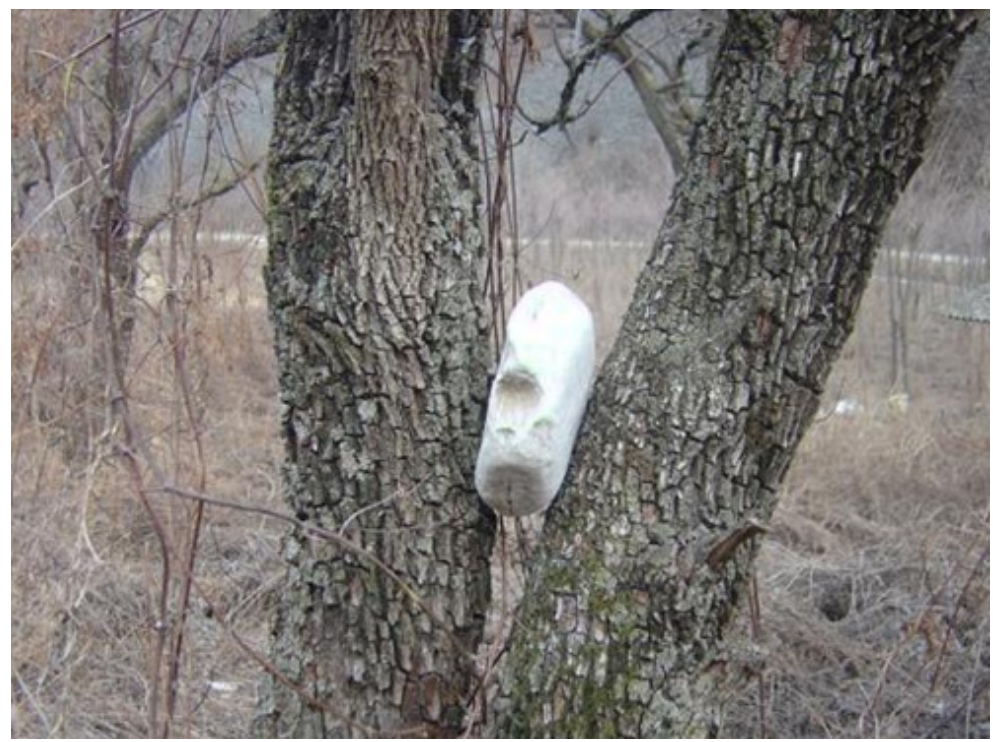

3. kép. A fa kiházasitása

Ezt a szülőtisztelet egyik kötelező pontjaként értelmezték, hiszen a családi vérvonal fenntartásához, a család vagyonának átörökítéséhez fiúra volt szükség a korabeli örökösödési szabályok szerint. A fiúgyerek előtérbe helyezése azonban a korábbi, kevésbé konfuciánus korokban is előfordult. Már a Három királyság idejéről szóló történelmi krónikák történeteiben is, de akár az első államalapítóhoz kapcsolódó eredetmítoszban is találtak erre utaló elemeket. A Tangun-mítosz ${ }^{16}$ egyik narratívája a következőt tartalmazza:

$$
\begin{aligned}
& \text { 웅녀(熊女)가 그와 결혼해 주는 이가 없으므로 매일 } \\
& \text { 신단수(神壇樹) 아래에 가서 아이를 잉태하고자 정성을 다해 } \\
& \text { 빌었다. }{ }^{17}
\end{aligned}
$$

A medvenőnek mivel nem volt kivel elhálnia a házasságot, mindennap elment Shindansu ${ }^{18}$ alá, és minden erejével azért imádkozott, hogy megfoganjon a gyermeke. ${ }^{19}$

\footnotetext{
16 Az első koreai államalakulat és a koreai nép eredetmítosza, amely egy medve és egy tigris kihívásáról szól. Az Ég királyának a Földre érkezett fia végül feleségül veszi a nővé átalakult medvét, nászukból pedig megszületik Tan'gun wanggŏm, az első király.

17 „Kija”, Folkency Encyclopedia of Korean Folk Culture (online).
} 
Ha a további történelmi narratívákat is megvizsgálnánk, különböző fajta gyermekáldással kapcsolatos rítusokat találhatnánk a történetekben, ezek között vannak kifejezetten sámánszertartások, de közemberek által elvégzett különböző felajánlások, különleges ételek fogyasztása, nemi szerv alakú kövek vagy egyéb természetbeli tárgyak előtti leborulás stb. ${ }^{20}$

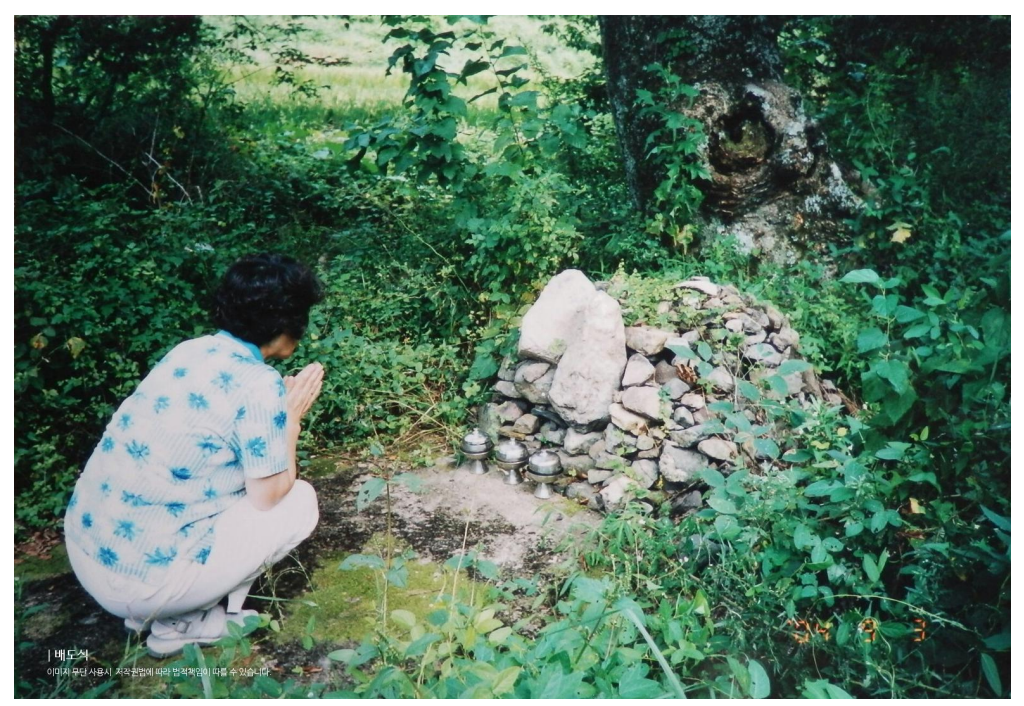

4. kép. Imádság a gyermekáldás érdekében

A fogantatásért tehát a koreaiak hiedelemvilágában különféle természetfeletti lények, istenségek felelnek, ide tartozhat többek között a hegyisten, Buddha, a kút vagy forrás istene, a konyha istennője, Jáde Sárkány égi király, különböző égi királyok, például Komokshin 고목신 高木神, de mindezek közül is a legfontosabb a születés istensége, akit Samshinnak neveznek. Ö a fogantatástól kezdve a szülőanya és a magzat egészségén át az újszülött biztonságos növekedéséig a születés sikerességéért felel. Valószínüleg a legkorábban tisztelt istenek közé tartozik, a sámánizmussal és az otthonhoz kötődő hiedelemvilággal egyaránt kapcsolatban áll. Legtöbbször két különböző elnevezést használnak rá, vagy a már említett Samshint, azaz hármas istenséget 삼신 三神, vagy a szü-

18 Shindansu 신단수 神壇樹 az eredetmítosz szerint annak a fának a helye, ahol az Ég királyának fia lejött, és az első várost alapította.

19 Saját fordítás.

20 „Kija”, Folkency Encyclopedia of Korean Folk Culture (online), illetve „Kija”, Koreai Néprajzi Nagyenciklopédia I. kötet, 213-215. 
letés istenségét jelentő Sanshint 산신 産神. ${ }^{21} \mathrm{Az}$ elnevezésében a hármas szám magyarázatára több elképzelés is van, viszont a neve miatt az áldozati asztalokon $^{22}$ rendszerint mindent hármasával helyeznek el. ${ }^{23}$ Azért, hogy megfelelő módon tudjanak elöre leborulni, különböző módokon meg is próbálják jeleníteni, ez a sanshindanji 산신단지. Legtöbbször például egy kiszárított töktálba rizst és mellé a hosszú élet szimbólumát, cérnát tesznek. A rizst időközönként frissre váltják. Más helyeket fehér hanji papírt, illetve tengeri hínárt is alkalmaznak. Általában a belső szobában helyezik el, és nemcsak a születés után vagy annak előkészítésekor, hanem egész éven át ott van, és figyelnek rá, a neves ünnepeken pedig ugyanúgy áldoznak neki. ${ }^{24}$

Ezen kívül gyakran bevetett praktika volt kisgyerekes házból vagy olyan családtól, akinél épp csecsemő érkezett, rizst és hínárlevest kérni, majd elfogyasztani vagy a szülőanya ruháját kölcsönvenni, illetve akár az érintett család tudta nélkül a születéssel kapcsolatos dolgokból eltulajdonítani, ilyen például a kŭmjul - ezt aztán elégették, a hamvát vízbe keverték, és megitták. Úgy gondolták, ezzel a termékenység áldásából nekik is jutni fog. Főleg fiúgyermekre való áhítozás esetén ezüstből készült kis tárgyakat, például fejszét hordtak a testükön vagy a ruházatukra akasztva. ${ }^{25}$

\section{A fogantatási álom}

A fogantatási álom, azaz t'aemong 태몽 胎夢 egyszerüen fogalmazva: a megfogant gyermek létét jelezte. Ez alapján az anyaméhben növekvő magzat nemét, esetleg jövőbeli sorsát is meg lehet jósolni. A korai feljegyzésekben, például az időszámításunk kezdete körül fennálló koreai birodalmak alapító mítoszairól szóló történetekben főleg leendő legendás uralkodó vagy trónörökös érkezésének az előrevetítése miatt emlékeztek meg ezekről, a konfuciánus társadalom erős patriarchális rendszere pedig a férfiág (pugye 부계 父系) fenntartása, a fiúgyermek születése miatt tartotta fontosnak. Nagyon

21 Koreaiul emlegetik még a következő neveken is: Samshinhalmŏni 삼신할머니, Samshinhalmae 삼신할매, Chianghalmi 지앙할미, Samshindanji 삼신단지, Samshinbagaji 삼신바가지, Samshinjumŏni 삼신주머니, Samshindongu 삼신동우.

22 Ld. alább a születéssel kapcsolatos rítusoknál.

23 „Samshin”, Folkency Encyclopedia of Korean Culture (online).

24 „Sanshindanji”, Koreai Néprajzi Nagyenciklopédia, II. kötet, 769.

25 Pyo-Han 1997: 169-172. 
sokszor különböző égitestek, a Nap, a Hold, a csillagok vagy istenségek alakjai tünnek fel az álmokban. A Nap és a Hold esetében ezt irwŏl t'aemongnak 일월 태몽 日月胎夢 nevezik, és már a Shilla-korból, konkrétan 884-ből a Borim buddhista templomból maradt fel róla feljegyzés. Csillagok esetében sŏngshin t'aemongnak 성신 태몽 星辰胎夢 hívják, szintén már a Shillakorból származnak ilyen történetek, amikor a nő ölébe egy csillag hull. Ezek az égitestek általában fiúgyermek érkezését jelzik, a Hold és a Nap is hullhat valakinek az ölébe, vagy épp lenyelik ezeket álmukban, így valósul meg a fogantatás. Az istenséggel kapcsolatos álmokat shinin t'aemongnak 신인 태몽 神人胎夢 nevezik. Az ilyen történetekben egy égi istenség átad valamit, például egy virágot vagy virágcsokrot egy földi nőnek, vagy Buddha maga átalakult testben érkezik a Földre, vagy egy istenség az alvó nő párnája alá bújik. Vannak gyöngy vagy drágakő lenyelésével kapcsolatos álmok is, ez a chinbo t'aemong 진보 태몽 珍寶胎夢. Előfordulnak drága kincseknek számító tárgyak, aranypohár, aranyöv, arany hajtü, tükör, selyemruha stb. ezekben a narratívákban. Zöldségek és gyümölcsök, állatok (tongshingmul t'aemong 동식물 태몽 動植物胎夢) is jelezhetik gyermek születését. Uborka vagy hosszú padlizsán megjelenése egyértelmủen fiúra utal, de ilyen még a sárkány, a kígyó, a daru, az ökör, a ló és a teknős is. ${ }^{26}$

Az általam használt néprajzkutatók által lejegyzett források is számtalan verziót tartalmaznak, a már említettek mellett a paprikát az ölében gyüjtő nő, a szoknya alá bekúszó kígyó, a kútból felröppenő daru is megjelenik. A nemek szerint is csoportosíthatók a szimbólumok. Fiúra utalhat még a disznó, a tigris, a kakas, a gesztenye is, lányra pedig kisebb halak és kígyók, a tyúk, a tojás, a barack, a lótusz, az üröm, az alma, a tök, a gyürü. Általánosságban úgy lehetne összefoglalni, hogy a fiúgyerekre az erőteljesebb, hatalmasabb állatok és jelentős égitestek, a lányokra a kisebb állatok, színesebb növények és gyümölcsök utalhatnak. Ugyanakkor nem mindegyik álom hordozott szerencsés jelentést, a halott állat képe a halva születést, a tüz pedig a nehéz szülést vagy a rövid életet vetítette előre. ${ }^{27}$ Érdekesség, hogy míg a születést övező sok szertartás fokozatosan kikopott az emberek életéből, a t'aemongban való hit a mai napig megmaradt. Fiúhoz még a XX. század elején említették a jól megérett gyümölcsöket, a pirospaprikát, a retket, a kukoricát, a bikát, a pontyot, a tengert, a hegyet és a villámokat, lányhoz pedig főleg virágokat, nyulat, bárányt,

26 „T'aemong”, Koreai Néprajzi Nagyenciklopédia, II. kötet, 1440-1441.

27 Pae 1981: 87-98. 
csibét, szivárványt és tüt. A második világháború utáni gyüjtésekből hozzátehető még a fácán, a vaddisznó, lányhoz pedig a hal, a kígyó és az oroszlán is. Negatív tartalommal bírt egy-egy állat, például a kígyó vagy hal megölése az álomban, ez a vetélést jelentette. ${ }^{28} \mathrm{Az}$ ilyen álmokat általában maga a leendő édesanya, esetleg annak anyósa, édesanyja vagy közeli barátja álmodta meg. ${ }^{29}$ Többször kérdeztem meg koreai ismeröseimet, hogy tudnak-e róla, születésük elött az ő édesanyjuk álmodott-e valamit, amit t'aemongnak véltek. Egyikük azt mesélte, hogy a sajátját ugyan nem tudja, de amikor kislány volt, az édesanyja két fókáról álmodott. Ez alapján azt hitték, hogy ikerterhességről lesz szó, és két öccse fog születni. Hamarosan orvosilag is megerösítették a terhességet, viszont csak egy babával. Ugyanakkor majdnem egy időben az édesanya húga is teherbe esett, és szintén fiút szült, akik így tehát majdnem egykorú unokatestvérek lettek. Ez a példa alátámasztja azt is, hogy nem mindenki saját életére vonatkozóan látja az álmot, viszont közeli ismerősök vagy rokonok álmodhatnak neki. A koreaiak manapság hobbiszerüen dokumentálják ${ }^{30}$ életüknek nagyobb eseményeit, így nem kerül nagy erőfeszítésbe egészen aktuális információk kikeresése a blogokról. A t'aemongot is szinten minden leendő kismama emlegeti, és megosztja az internetes olvasókkal.

A t'aemong nemcsak nemet, hanem a sorsra vonatkozó jövőbeli kilátásokat is tartalmazhat. A sárkányos álom kifejezett egy jelentős személyiség, híresség vagy nagy hatalomra szert tevő ember születését jelzi. A tigris jó vezetőképességü fiú érkezését mutatja. A kígyó a bölcsességet, a disznó a vagyont, a ló a könnyen jól alakuló életet, a nemesfémek pedig a hírnevet jósolják. A halaknál a fajta is számít, a ponty esetében a híres, nagy személyiség, aranyhal esetében a müvészeti érzék mutatkozik meg, horgászat vagy halászat során kifogott harcsa a kellemes személyiséget, a sok barátot vetíti előre. A madaraknál a főnix az okos és tevékeny személyiséget, a daru a tudományos beállítottságot, a fecske vagy veréb a jó külsőt és a sokszínű tehetséget mutatja. ${ }^{31}$

\footnotetext{
Kim-Lee 2003: 143-151.

Pyo-Han 1997: 169-172.

30 Dél-Korea manapság a világ vezető internethatalmai közé tartozik, amelynek előnyeit a lakosság napi szinten élvezi és kihasználja. Az információáramlás nagyon gyors, szinte minden újdonságról az interneten próbálnak bizonyosságot szerezni. Az elmúlt évtizedtől kezdve pedig számtalan történet jelenik meg megosztófelületeken, amelyek átlagos emberek mindennapi tapasztalatait, utazási élményeit, problémáit, javaslatait és kérdéseit tárják a világ elé.

31 „Ŏjetpam kilmongi hokshi t'aemong?”, Mom 's diary (online).
} 


\section{Szülés előtti szokások és tabuk ${ }^{32}$}

Amikor már bizonyosan tudták, hogy új családtag fog pár hónapon belül érkezni közéjük, szigorú szabályok szerint töltötték el a mindennapjaikat. A következőkben felsoroltak főleg a várandós anyákra vonatkoztak, de többet közülük a férjének, illetve a velük egy háztartásban élőknek is be kellett tartania. Amint korábban már említettük, hogy bizonyos esetekben a szomszédságból lophatnak rizst vagy különféle ételeket - ugyanakkor temetési szertartás, elhunyt ösök megemlékezésének a szertartása (chesa 제사) vagy egyéb ünnepi lakoma (chanch'i 잔치) után megmaradt ételböl tilos volt fogyasztani. Hasonlóképpen a közvetlenül elejtéssel, például vadászattal szerzett étel is kerülendő volt tisztátalansága miatt. Több esetben bizonyos asszociációkhoz kötötték, hogy mi miért nem ajánlatos. A kacsahús fogyasztásától a baba ujjai között is úszóhártyaszerü képződmény nőhetne. A nyúl több külső tulajdonsága, mint a megnyúlt fül, furcsa alakú ajkak vagy a piros szem is nemkívánatos volt, így nyúlhúst sem ehettek. A tyúk furcsa bőrt okozna. A szálkamentes hal vagy tintahalszerü, szilárdabb testszerkezettel nem rendelkező élőlények fogyasztása gyenge csontokat vagy ezek hiányát eredményezné. A szamár húsa nehéz szülést, az uborka rossz természetet, bizonyos ételek pedig akár vetélést is okozhatnak. ${ }^{33}$ Továbbá a verébhez vagy fácánhoz hasonló madarak rövid életűek, ezért ezt a húst is kerülniük kellett. Bizonyos ételek nem feltétlenül a külső megjelenésre, hanem a gyerek jellemére vagy jövőjére is hatással lehettek. Régiónként eltérő szabályok voltak érvényesek. ${ }^{34}$ Általánosságban a jó minőségü ételeket kell a leendő anyának választania, ami már rothad, vagy valamilyen bogár megrágta, azt nem szabad. Ügyelnie kell a mértékletességre is, az étkezést sem vihette túlzásba, alkoholt pedig alapvetően kevésbé volt szabad fogyasztania. ${ }^{35}$

A tilalmak nemcsak az étkezésre, hanem a viselkedésre is vonatkoztak. Egy várandós nő nem láthat holttestet, így értelemszerüen temetési szertartá-

32 A tabu koreaiul kŭmgi 금기 禁忌, beszédre és magatartás vonatkozó szabályokat is magába foglal. Általában a tisztasággal és tisztátalansággal, pozitív és negatív hatásokkal van kapcsolatban. Lehet vallásos befolyás eredménye, de a nép hiedelemvilágnak vannak ezen kívül is követendő szabályai. A megtisztítás érdekében később különféle szertartásokat, akár sámánrituálékat is tarthatnak (Encyclopaedia of Korean Culture, online).

33 Pae 1981: 87-98.

34 „T'aegyo”, Koreai Néprajzi Nagyenciklopédia II. kötet, 1437.

35 Kim-Lee 2003: 138-143. 
sokon nem vehet részt. Valamint olyan szertartáson sem tartózkodhat, ahol elhunyt lelkekkel találkozhatna, legyen az megemlékező szertartás vagy sámán kut. ${ }^{36}$ Hasonlóképpen halott állatokat sem pillanthatott meg, így például mészárszékre sem látogathatott el. Ha éppen költözésre készült a családja, akkor figyelembe kellett venni, hogy olyan helyre, ahol bedugult az árnyékszék vagy a kút, illetve túl közel volt egy sírhely, nem építkezhettek. Ellenkező esetben nehéz szülés vagy halva születés lenne a következmény. Nem tartották szerencsésnek, ha egy háztartásban vagy egy családban, ugyanabban a hónapban több csecsemő is a világra jön, mert a születés istensége ekkor megharagszik, és csak az egyikre fog majd vigyázni, a másik pedig nem marad életben. A szülés hónapjában nem volt szabad a házon, főleg a szülőszobának kijelölt helyiségben és a konyhában javításokat végezni. A kismama továbbá nem léphetett a küszöbre, és a ház területére is csak a fökapun jöhetett be. A konyhában is vigyáznia kellett, ugyanis ha egy szikra lyukat égetett a szoknyájába, akkor azon egy ártó szellem ( $a k k w i$ 악귀 惡鬼) bemehetett volna. Annak érdekében, hogy ezt elkerüljék, általában vörös anyaggal foltozták be a szakadást - a piros, a vörös a hagyományos koreai szokásokban gyakran a rosszat, ártó szellemeket távoltartó színként jelenik meg. ${ }^{37}$ A XIX. század végéig általánosan betartották azt az alapszabályt, hogy a várandós nő rosszat ne lásson, ne halljon, ne gondoljon. A gondolkodásmódjával ugyanis közvetlenül hat a magzat fejlődésére és kialakuló jellemére, így nem engedhette meg magának a negativitást, a félelmet, az aggodalmat. Nem volt szabad megerőltetnie magát, testtartására és az ülőpozícióra is külön oda kellett figyelni. Nem mindig a kényelmes volt ajánlatos. A családtagokra is vonatkozott a viselkedés kordában tartása. A kismama jelenlétében nem volt szabad veszekedni, hangoskodni, rossz híreket hangoztatni, valakit sürgetni vagy leszidni. ${ }^{38}$

Azokat az irányelveket, amelyek a magzatra való hatások szabályozása érdekében alakultak ki, összefoglaló néven t'aegyonak 태교 胎敉 nevezzük.

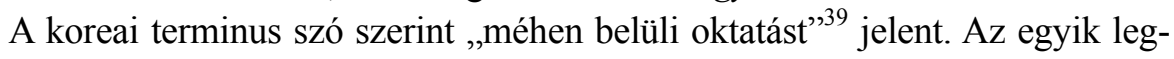
fontosabb betartandó kötelességnek tartották a minél kiemelkedőbb utódok világra hozatalát, ehhez a terhesség alatt és a szülés folyamán a generációkról generációkra átadott szabályokat követték. Ennek szabályait az idők során le

\footnotetext{
36 Hasonló tabuk és tilalmak voltak megfigyelhetők a hagyományos japán társadalomban, ennek részleteihez ld. Papp 2018: 121-132, illetve Papp 2011: 227-248.

Pae 1981: 87-98.

Kim-Lee 2003: 138-143.

Koreaiul t'aejunggyoyuk 태중교육 胎中敉育.
} 
is jegyezték, föleg kínai mintára. Ezek a szövegek leginkább a várandós nő környezetére, annak életvitelére, étkezési és ruházkodási szokásaira, testi és lelki harmóniájának a fenntartására vonatkoztak. Tilos volt számára, hogy ő maga egy élőlényt leöljön, lopjon vagy hazudjon, nehéz dolgokat cipeljen, vagy nehéz munkát végezzen, és különösen a szülés idöpontjának közeledtével nem volt szabad elhagyni a házat vagy utazásra vállalkoznia, helyette a megfelelö pihenésre és korlátozott testmozgásra ösztönözték, hogy testileg és gondolatban is a szülésre készülödjön. ${ }^{40}$ Kerülnie kellett a hideg dolgokat vagy a hideg ételek fogyasztását, inkább törekednie kellett arra, hogy megfelelően melegen tartsa a hasát, csípős és túl sós ételeket sem ehetett, a saját müvelődésére viszont gondot kellett fordítania, különös tekintettel a gyermekgondozási és nevelési ismeretekre. Ezek a szabályok a gyermeket váró házaspár mindkét tagjára vonatkoztak. Kifejezetten az apának kellett betartania, hogy az együttlétet ne vigye túlzásba föleg a terhesség elején, mert már akkor is köztudott volt, hogy az könnyen vetéléshez vezethet. A terhesség végén pedig azért tiltották tőle, hogy nehogy koraszülött legyen a csecsemő. Oda kellett figyelni a különböző fertőzések miatt a terhesség középső szakaszában is a házasélet intenzitásának féken tartására. ${ }^{41}$

Egy másik szabály az égi, földi, emberi tilalmak ${ }^{42}$ betartása. Ez azt jelenti, tilos volt a szexuális együttlét a következő esetekben: hónap első napja, telihold, hónap utolsó napja, esős és viharos nap, havazás, ködös idő, csípős hideg, hőség, napfogyatkozás, holdfogyatkozás, földrengés napja - ezek az éghez köthető elemekkel kapcsolatos hatásokat előzték meg. A földi tilalom az együttlét helyszínére vonatkozott, ennek értelmében nem volt szabad olyan helyen, amelyet ért a Nap, Hold vagy a csillagok fénye, tüzhely vagy fatüzelésủ kályha, buddhista templom, sírhely, holttest vagy árnyékszék közelében helyezkedett el, azaz úgy volt megítélhetö, hogy az illetlen viselkedést jelentett volna. Az emberi tényező pedig azt jelentette, hogy a két fél testileg és lelkileg is megfelelö állapotban kellett, hogy legyen (shimshin kŏn'gang 심신 건강 心身健康). Ezért alkohol befolyása alatt vagy tele hassal, közvetlenül betegség után, fürdőtől vizesen, aggódva vagy szomorúan, a másikra haragudva

40 Bizonyos tilalmak származhatnak gyógyászati megfontolásból. A Koreai-félszigeten is már évszázadokkal korábban kezdett fejlődni a saját népi gyógyászatuk, amelyre részben a kínai orvoslás hatott. Ezt egészítették ki a helyi ismeretekkel és tapasztalatokkal, vagy bizonyos esetben helyettesíteni próbálták a kínai mintát a koreaival.

41 „T'aegyo”, Koreai Néprajzi Nagyenciklopédia II. kötet, 1437.

42 Koreaiul ch'ón'gi 천기 天忌, chigi 지기 地忌, $i n^{\prime} g i$ 인기 人로. 
vagy utálkozva nem volt szabad szexuális kapcsolatot létesíteni. ${ }^{43}$ Ezen szabályokat összefoglaló írásbeli mü is létezett, amely a T'aegyoshin'gi 태교신기 胎敎新記 ${ }^{44}$ címet viselte. Ebben javarészt a már korábban említett tilalmakat listázták tételesen, hogy mit nem szabad, és mit kell látnia, hallania, mit nem lehet mondani, hogyan nem lehet és hogyan kell cselekedni. ${ }^{45}$ Ezek a szabályok a korábbi korok felfogását is tükrözhetik, valamint az is látszik belölük, hogy valamennyire tisztában voltak bizonyos dolgok emberi szervezetre, egészségre gyakorolt hatásával az orvostudomány viszonylagos fejletlensége ellenére is, és a pszichológiai vonatkozásokra is eléggé odafigyeltek. ${ }^{46}$ A születendő gyermek a család fenntartása érdekében nagyon fontos és értékes jövevény, akit az égiek ajándékának is tartottak, ezért vele gondatlanul bánni, ezt elveszíteni nagy szerencsétlenségnek számított. A magzat megtartására is voltak praktikáik, például kisebb ezüsttárgyakat vízben megföztek, majd a levet megitták, valamint tökböl és különféle levelekből készített fözetet is fogyasztottak. Ezen szabályokat rendszerezni is tudjuk, a samt'aedo 삼태도 三胎道 vagy a ch'ilt'aedo 칠 태도 七胎道 szerint. Ez a magzati nevelés három, illetve hét szabálya.

43 Ld. még: Kim-Lee 2003: 207-208.

44 A müvet 1801-re készítette el Sajudang Lee 사주당 師朱堂 이씨李氏 nevü hölgy kínai karakterekkel, a saját terhessége idején tapasztaltak alapján. A mű azért is kivételes, mert ebben az időszakban kevés volt az olyan nő, aki tanult és írt, föleg kínai karakterek használatával. Tíz fő gondolatát a következőképpen lehetne összefoglalni:

1. az ember a jellemét az égtől, a szellemiségét a szüleitől kapja;

2. a fogantatásra közvetlen befolyással van az elmeállapot;

3. a magzatnak már egy erkölcsös nemesember viselkedését kell tanítani;

4. a szabályok az egész családra vonatkoznak;

5. hogy kiből lesz erkölcsös és kicsinyes ember, az a magzati neveléstöl függ;

6. ha a magzati nevelést nem veszik komolyan, a baba teste nem lesz tökéletes, gyenge lesz;

7. a buddhista szútrák olvasását és a sámánok hívását minimálisra kell csökkenteni;

8. a magzati nevelés logikája megingathatatlan, alapja, hogy a csecsemő élete az édes anyjától függ,

9. kínai minta alapul vehetö;

10. alapvetően az utódok érdekében kialakult szabályok, amelyeket a feleségeknek és a lányoknak tudniuk kell

(,Taegyosingi”, Folkency Encyclopedia of Korean Culture, online).

45 Chin 2016: 128-135.

46 „T'aegyo”, Koreai Néprajzi Nagyenciklopédia, II. kötet, 1437. 
1. Alapvetö tabuk, hogy a szülés napján ne mosson hajat, ne menjen magas helyre, ne igyon alkoholt, ne emeljen nehezet, patakon át ne keljen;

2. ne beszéljen vagy nevessen sokat, ne sírjon, ne féljen;

3. helyszín (megfelelö és kerülendő megkülönböztetése);

4. pihenés, jó dolgok olvasása és hallgatása, vers és kalligráfia;

5. testtartás;

6. méltóság;

7. kevés fürdés. ${ }^{47}$

Érdekesség, hogy szinte mindegyik forrás külön említ példákat arra, hogy az önmüvelés mennyire fontos a várandósság alatt. A különböző olvasmányok, képek megtekintése, szútrák vagy irodalmi alkotások olvasása, az ének és zenehallgatás mind pozitívumnak számított ${ }^{48}$ - kérdéses ugyan, hogy ez utóbbiak a nem magasabb társadalmi osztályból származó szülőanyáknál mekkora fontossággal bírhattak, vagy mennyire voltak megvalósíthatók.

\section{A szüléssel kapcsolatos szokások}

Az édesanya és családjának főleg női tagjai, amikor már érezték a szülés órájának közeledtét, különböző rituálékat végeztek el, még mielőtt a gyermek világra segítése megkezdődött volna. A könnyü szülés szimbolikus vonzására minden kötött dolgot feloldottak, a házon belüli tárgyakon a csomókat kibontották, edények fedőjét levették, ajtókat kinyitották, az eldugult árkokat megtisztították, még akár az egérlyukakat is szabaddá tették. A vajúdás ideje alatt „kölcsönvették” a férj férfierejét is, az édesanya férjének a ruhadarabjait a hasára terítette. ${ }^{49}$ A szülés megsegítésére elhívott legfontosabb alak mégis a születés istensége (samshin 삼신 三神) ${ }^{50}$ volt. A samshin halmŏninak 삼신 할머니

\footnotetext{
Pae 1981: 87-98.

Kim-Lee 2003: 138-143.

Pae 1981: 98-106.
}

$50 \mathrm{Az}$ istenségnek több elnevezése is létezik. A samshin szó szerint három istenséget jelent, de volt, hogy egy vagy két alakot képzeltek el. Más magyarázat szerint a hármas elnevezés az eredetmítosz három alakjára, Hwanin, Hwanung és Tangun hármasára utal. Ugyanakkor kiejtés tekintetében nem sokban tér el a sanshin 산신 産神 elnevezés sem, amelynek jelentése a kínai karakterek szerint is a 'születés istensége'. Hozzátehetjük még, hogy a kínai karakterekkel $t^{\prime}$ aenek 태 胎 írt 'placenta' koreaiul eredetileg sam, és a szüléssel kapcsolatos régi koreai szavakban megjelenik (Koreai Néprajzi Nagyenciklopédia, II. kötet, 768-769). 
is nevezett istenség az Égi király által az emberi világba küldött istenség, akinek feladata a csecsemők számának szabályozása, a könnyü szülés megsegítése és a gyermek fejlődésének vigyázása egészen annak 15 éves koráig. ${ }^{51}$ Amíg a házban kisgyerek nevelkedett, az istenség fizikai megjelenítésére bizonyos térségekben használtak egy rizzsel megtöltött töktálat, amelybe hajtogatott hanji papírt tüztek, és egy szerencsésnek ítélt helyre állították a házban. A tartalmát általában évente cserélték. Ezt a már korábban is említett tárgyat samshindanjinak 삼신단지 nevezték, megjelenési formája régiónként eltérő volt. Cheju szigetén például nem volt külön tárgy erre, mert a szigeten egyébként is erős a születés istennőjének kultusza (helyi nyelvjárásban samsŭnghalmangnak 삼승할망 hívták), így ők egy sámánrituálé alkalmával fö istenségként hívták öt el. ${ }^{52}$
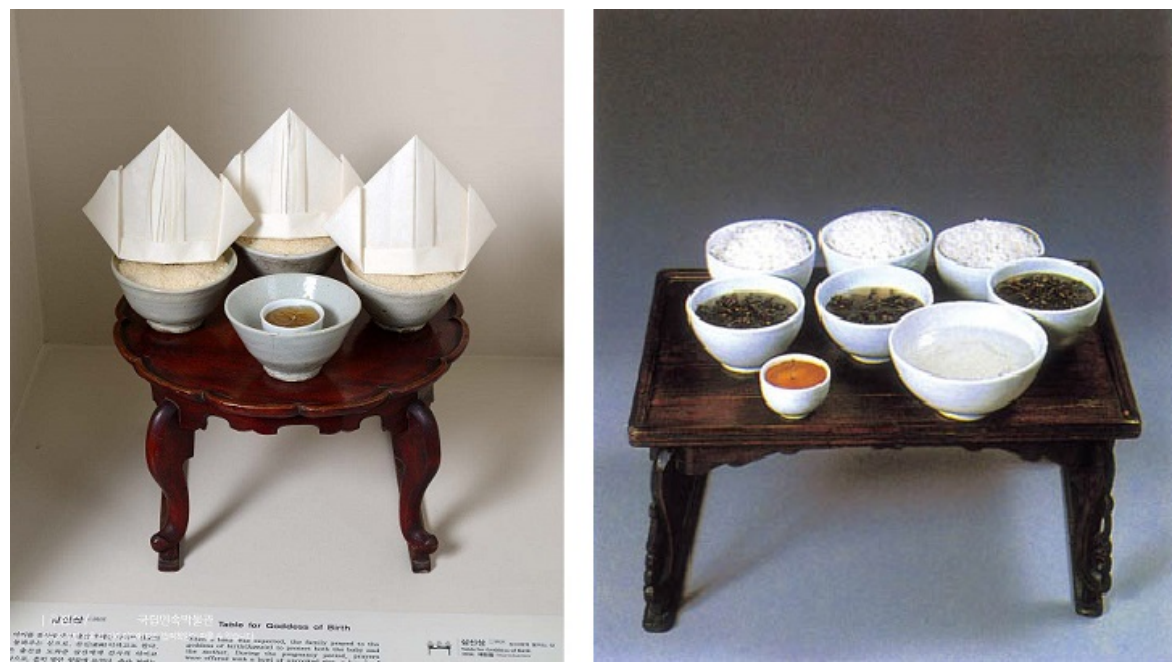

5-6. kép. Áldozati asztal a születés istenségének

A születés istenségének a fogadására ezen kívül a legtöbb háztartásban egy kisebb áldozati asztal állítottak fel, ez volt a samshinsang 삼신상 (5. és 6. kép). Ezt általában a leendő nagymama készítette el, egy gyékényt leterítve a szoba szerencsésnek ítélt irányában elhelyezte az asztalt, majd arra a hármas elnevezésnek megfelelően három tányér rizst és három tányér hínárlevest, ${ }^{53}$ va-

\footnotetext{
51 „Samshin”, Koreai Néprajzi Nagyenciklopédia, II. kötet, 768-769.

52 „Samshin”, Koreai Néprajzi Nagyenciklopédia, II. kötet, 769.

53 A hínárleves fontosságáról bővebben a további bekezdésekben.
} 
lamint egy vagy három tál tiszta vizet tett. Ez kiegészülhetett a hosszú életet jelképező cérnával, a bőséget jelképező pénzzel vagy kisfiú esetében pirospaprikával. Az asztal általában hét vagy a hét valahány szorzatával megfelelő számú napig (ire 이레) maradt, és ez előtt imádkoztak a csecsemő fejlődéséért, az elegendő anyatejért, a rossz távoltartásáért. ${ }^{54} \mathrm{Az}$ ilyen hiedelemvilágban tisztelt istenségekhez való imádkozást koreaiul pisonnak 비손 nevezik, ez az elnevezés szó szerint a „kezek összedörzsölését, összekeverését” jelenti. ${ }^{55}$ Ehhez az asztalhoz fordultak később a születés utáni 100. napon, illetve a baba első születésnapján is, ugyanis az előző évszázad elejéig főleg, amikor magas volt a csecsemőhalandóság, ezek az napok különösen megünneplendő időszakoknak számítottak. Ekkor a már felsorolt áldozati ételek mellett rizssütemény is kerülhetett az asztalra. ${ }^{56}$ Amikor úgy döntenek, hogy az asztalt lebontják, akkor a rizst megfözték, és az édesanya fogyasztotta el, a vizet pedig egy tiszta helyre öntötték ki. Előfordult, hogy a rizsből ajándékoztak olyan nőknek, akik szintén teherbe szerettek volna esni. ${ }^{57} \mathrm{Az}$ istenség megfelelő vendégül látása nagyon fontos volt, mert ha esetleg elhanyagolják, elhagyhatja a házat és ezzel a szülőanyát, így ez a későbbi gyermekáldásra is hatással lehet. Erejét olyannyira fontosnak tartják, hogy aki nagyon vágyik a gyermekre, képes ilyen asztalról rizst lopni, de a szülőszobából később az édesanya véres ruhadarabjaiból is titkon visznek el, mert abban konkrétan az istenség erejét vélik felfedezni. ${ }^{58}$

A szülés levezetésében sokszor bába is segédkezett. Ezek a középkorú nők természetesen akkoriban nem orvosi ismereteket elsajátított, képzett szakemberek voltak, hanem olyan korosabb nők, akik több szülésnél is jelen voltak, és tapasztalataik alapján már-már foglalkozásként végezték a csecsemők világra segítését. ${ }^{59}$ Koreaiul sanp'anak 산파 産婆 nevezték, ${ }^{60}$ szolgálataiért pedig

54 Pae 1981: 103, illetve Pyo-Han 1997: 169-172.

55 „Pison”, Encyclopaedia of Korean Culture (online), illetve „Pison”, Koreai Néprajzi Nagyenciklopédia I. kötet, 718.

56 „Samshin”, Koreai Néprajzi Nagyenciklopédia, II. kötet, 768-769.

57 Pae 1981: 103.

58 Pae 1981: 87-98.

59 A XX. század elején már megjelentek a bábaságot valóban foglalkozásként végző asszonyok is. Ezek lehettek korábban nővéri szolgálatot végző nők, mint például a függetlenségi harcokban is részt vevő Park Jahye, de a XIX. század legvégén érkezett külföldi misszionáriusok tanításának eredményeként is egyre többen tanulhatták meg többek között a bábaság fortélyait. (Bővebben ld.: Kovács 2016: 139-190.) Ez a szakma azonban az 1950-es évektől intézményesebbé vált, elnevezéseire és gyakorlatára 
ruhákkal ajándékozták meg. A szüléssel kapcsolatos tabuk sokszor rá is kiterjedtek, az aktuális szülés után bizonyos számú nap elteltéig nem volt szerencsés más várandós háztartásba mennie. ${ }^{61} \mathrm{~A}$ bába szerepét sok esetben tapasztalatokkal rendelkező női családtag is betölthette, de ha nem találtak ilyet, akár sámánt is hívhattak a feladat elvégzésére. ${ }^{62}$

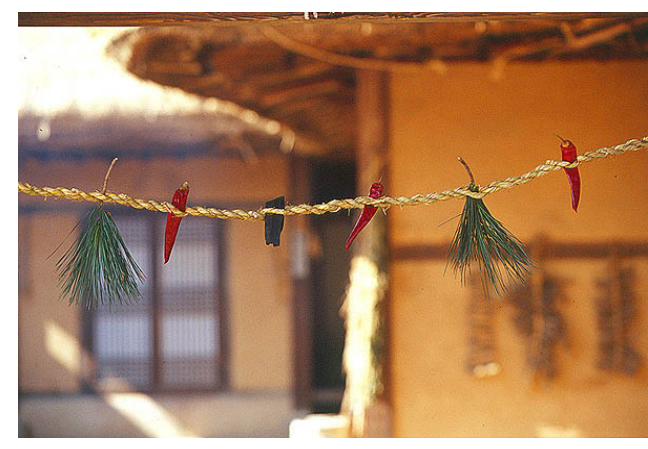

7. kép. 금줄 szalmafüzér

Annak érdekében, hogy illetéktelenek ne lépjenek be a házba a nehéz órákban és az újszülött csecsemő első napjaiban, a bejárati kapura egy kŭmjulnak 금줄 nevezett szalmafüzért akasztottak (7. kép). Ez a füzér különböző funkciókat töltött be. A szomszédság számára világosan tudatta, hogy a szülés lezajlott, így egy darabig nem kívánatosak a vendégek a házban. A füzérbe tüzött apró tárgyakról pedig megtudhatták az utód nemét is. Kisfiú esetén pirospaprika került rá, amely színével távol tartotta a rosszat, formájával pedig a férfinemiségre utalt. Lány esetében mindenképpen volt benne fenyő tülevele, illetve széndarabok. A szén szintén a tüzzel, a rossz távoltartásával kapcsolatos, a fenyőtü pedig a női tevékenységre, a varrásra utal. Előfordult, hogy emellett még amulett szerepét betöltő pujōkot 부적 符籍 is ragasztottak a kapura. ${ }^{63} \mathrm{~A}$ szal-

törvényi szabályozások is születtek (Shwimp'yo, mach'imp'yo 쉼표, 마침표. National Institute of the Korean Language online).

Elnevezése térségenként eltérő volt, így például Gangneung város környékén san'gwan hanŭn saram 산관 하는 사람, Chŏlla tartományban samhalmŏni 삼할머니, Cheju-szigeten pedig agihalmang 아기할망, agine uredengginŭn halmang 아기네 우레 뎅기는 할망, agi newajunŭn halmang 아기 네와주는 할망 stb. elnevezésekkel illették (Folkency Encyclopaedia of Korean Culture, National Folk Museum of Korea, online).

${ }^{61}$ Pae 1981: 105-106.

62 „Sanpa”, Folkency Encyclopaedia of Korean Culture (online).

63 Pae 1981: 80-81. 
mafüzért általában az édesapa vagy a nagypapa készítette el, füzte össze. Felakasztásához pedig kerülték a szög használatát. Amikor kislány született, néha akkor is tettek pirospaprikát a füzérbe, hogy ezzel a következö terhességhez a fiút vonzzák be. A szalmafüzér ugyanolyan hosszú ideig maradt kint, mint az istenségnek felállított asztal, tehát itt is hét nap vagy a hét szorzatai, főleg a 21 és a 49 nap fordulhatott elö. ${ }^{64}$

Különösen a királyi családban nagy jelentőséggel bírt a placenta elhelyezése. Úgy tartották, a méhlepény kihat a született gyermek sorsára egész életében, így nem dobták el hulladékként, hanem gondosan elhelyezték egy erre elkészített agyagedénybe ( $t^{\prime}$ aeong 태옹 胎䧶 vagy t'aehangari 태항아리, 8. kép), majd egy szigorú szabályok által meghatározott szertartással (ant'aeshik 안태식 安胎式) elszállították arra a helyre, ahol a földbe temették (ez a t'aeshil 태실 胎室, 9. kép). ${ }^{65}$ Kijelöltek ennek elvégzésére egy megfelelő napot és egy felelőst a hivatalnokok közül, mindezzel megelőzve a hirtelen bajokat. $\mathrm{Az}$ agyagedény földbe temetése után a föld istenségének is tartottak egy hálaadó szertartást, majd felállították a kŭmp'yot 금표 禁標, amely arra szolgált, hogy megtiltsa a helyszínnek a megközelítését. A meghatározott távolság eltérő lehetett, trónörökös esetében 540 méter, további hercegnők vagy hercegek esetében csak 180 méter. Ezen a területen belül nem volt szabad fát vágni, köveket kivésni vagy földet múvelni. Ha ezt valaki megszegte, törvény által kiszabott büntetéssel kellett szembenéznie. ${ }^{66}$ A királyi család szokásán kívül voltak még különböző módszerek a placenta megfelelő elhelyezésére, hiszen abban mindenki hitt, hogy a jövőre kiható erővel bír. A buddhista családok a szülés után felkeresték a buddhista templomot, és ott helyezték el a méhlepényt tartalmazó anyagedényt. Alacsonyabb társadalmi osztályokban a placentát sokszor elégették egy kijelölt szerencsés napon, majd a hamvakat szórták el, általában 3 vagy 7 nap után. Ezen mozzanat elérkezéséig több helyen az istenségnek felállított asztalka alatt tárolták. Cheju szigetén a vízbe temetés

64 Pae 1981: 104-105, ld. még: Pyo-Han 1997: 169-172, illetve Kim-Lee 2003: 143-148.

65 Például Sejong nagykirály 세종대왕 (r. 1418-1450) gyermekeinek születésekor a placentákat egy helyre temették, a sírokhoz hasonlóan kőszobrokkal borították, így ez a hely egy kisebb temető látszatát kelti. Ez ma is megtekinthető Sŏngjuban (Son Hyŏnhŭi: „Mi az a placentatemető?” Oh my news. 2007.11.29.). 2003 óta a 444. nemzeti kulturális kincsként tartják számon. (,Sŏngju sejongdaewangja t'aeshil”, Nemzeti kulturális kincs portál.)

66 „T'aeshil”, Encyclopaedia of Korean Culture (online), illetve „T'aeshil”, Koreai Néprajzi Nagyenciklopédia, II. kötet, 1442. 
volt az elterjedt szokás, ott hanji papírba csomagolva a vízbe dobták. Nem volt elhanyagolható a köldökzsinór sem. Ez ugyancsak olyan hatalmas erővel rendelkezett, amellyel egy következő gyermekáldást segíthetett meg. Esetenként ennek ellopására tettek kísérletet olyanok, akik már nagyon vágytak a gyermekre. A család azonban a megfelelő napon ezt is elégette, füstjével jelezték az istenségeknek a vágyat a következő utódra. Ha hamar elégett, akkor a következő csecsemőre rövid időn belül számíthattak is, ha az égés tovább tartott, akkor többet kellett várni. ${ }^{67}$

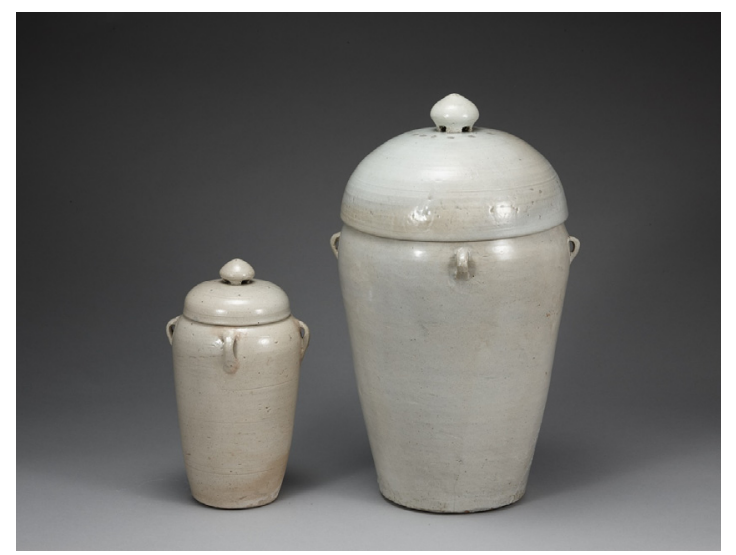

8. kép. 태 항아리 Kerámiaedény a placenta elhelyezéséhez

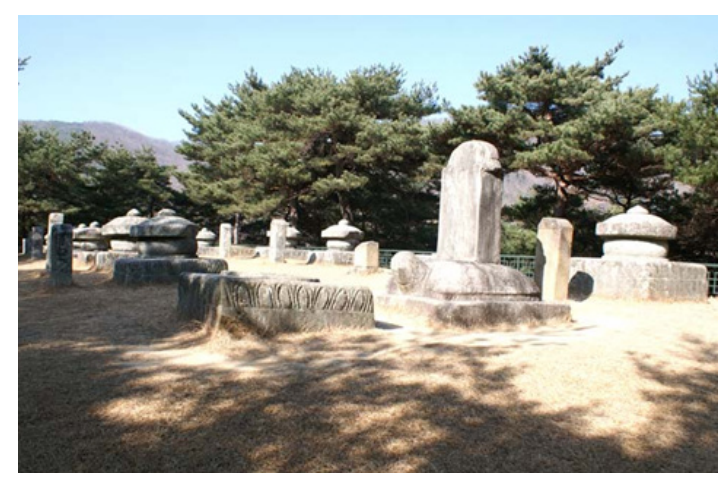

9. kép. Sejong király leszármazottainak „placentatemetője”

67 Pae 1981: 102-103, illetve Pyo-Han 1997: 169-172. 
Az édesanya felépülésében kulcsfontosságú szerepet játszott a hínárleves (10. kép). A már korábban említett áldozati asztalra ebből három tányérral helyeztek el az istenség számára. A szülésen túlesett anya pedig naponta akár több alkalommal is ezt fogyasztotta. A miyŏk leves ${ }^{68}$ 미역국 fogyasztása több társadalmi rétegben is több száz éves hagyománynak tekinthető, a modern orvostudomány pedig azóta tényekkel is alátámasztotta, hogy valóban jótékony hatással rendelkezik ez az étel. A magas jód- és kalciumtartalma segíti a szülés során esetleg sok vért veszített édesanya felépülését, valamint serkenti az anyatej termelődését is. Fogyasztásával sok tápanyagot lehet bevinni a szervezetbe, de mégsem terheli meg az emésztőrendszert. ${ }^{69}$ A hínárlevessel kapcsolatos kutatások a mai napig több országban folyamatban vannak, allergiacsökkentő, rákellenes, elhízást gátló hatásával foglalkoznak többek között koreai, japán, angol és amerikai egyetemek kutatóintézetei is. ${ }^{70}$

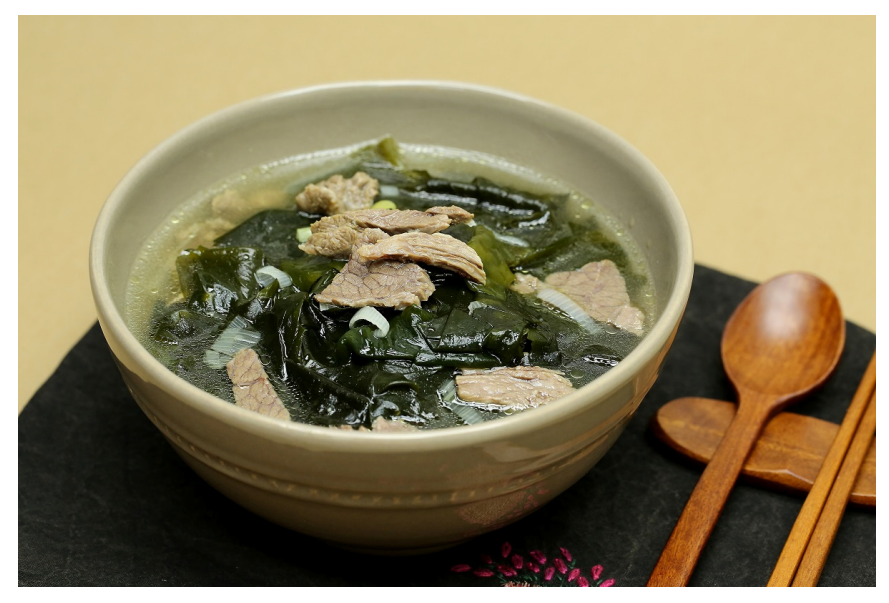

10. kép. 미역국 hínárleves

Az ételekkel kapcsolatban ezenkívül voltak még egyéb hiedelmek is. Rizssüteményt vagy lisztes ételeket nem ettek, nehogy elapadjon a tej. Az édesanya csak kevés levet fogyasztott, hogy ne öklendezze vissza a gyermek az anyatejet. Természetesen túl csípős vagy sós ételeket sem vett magához, valamint a szülés előtti különböző állatfélék húsára vonatkozó babonák miatt ezeket

\footnotetext{
68 „Miyŏkkuk”, Koreai Néprajzi Nagyenciklopédia, I. kötet, 567.

69 "Miyeok-guk (Korean Seaweed Soup) - Postpartum Recovery”, Bing's Natural Health (online).

70 Wright 2018.
} 
továbbra is kerülték. A mindennapi életben is odafigyeltek bizonyos cselekedetekre. A házból nem söpörtek ki semmit, és ekkor adósságot nem fizettek vissza. Nyitva levő lakatot nem zártak be, mert azzal rövid életet okoztak volna a babának. A csecsemőnek eleinte furcsa vagy egyenesen visszataszító neveket (angmyŏng 惡名 악명) adtak, hogy a szellemek érdeklődését ne keltse fel a gyermek, például ilyenek voltak az állatok ürülékére használt vicces nevek. ${ }^{71}$ A szabályaikat legalább 7, de sokszor 21 napig betartották. A szalmafüzért is a 21. napon vették le általában, ekkor még egyszer áldoznak a születés istenségének is, és az áldozati asztalon elhelyezett ételeket a családtagok közösen fogyasztották el. Ezután már fogadtak látogatókat is. ${ }^{72}$ A névadásban egyébként főleg a nagyszülők, de leginkább a nagyapa játszotta a föszerepet. Olyan nevet választott az unokának, amely hosszú, sikeres életet biztosíthatott a számára. ${ }^{73}$

\section{A hagyományos szokások helyzete és a jelenlegi gyakorlat a modern Dél-Koreában}

Az eddig bemutatott szokások, rítusok és tilalmak elsősorban az 1900-as évek elejéig voltak érvényben. A XX. század elején lassan megindult a modern orvostudomány beépülése a keleti gyógyászatba, napjainkban pedig domináns a koreaiak életében is. Ami azonban nem változott, hogy a gyermekvállalást és a várandósságot nagyon fontos időszaknak tartják, amikor fokozott figyelmet fordítanak az egészségükre, viszont nagyban támaszkodnak a nyugati orvostudományra. Ehhez természetesen hozzájárult a világháború után lezajlott modernizációs és urbanizációs folyamat is. Míg az 1950-es évekig egy koreai nő életében 5-6 gyermeket is a világra hozott, ma Dél-Korea a túl alacsony születésszám problémájával küzd.

A várandós édesanyák a modern időszakban sem tartják kevésbé fontosnak a születés előtti nevelést, csak a formája változott meg kissé. Továbbra is lényeges a pozitív viselkedés és gondolkodásmód, az olvasás és a zenehallgatás, de hagyományos koreai zene helyett ma már a nyugati klasszikus zenét is sokan választják. Tevékenységként jónak tartják az úszást és a jógát. A tiltott ételek közül a régiekhez képest már sok mindent babonának titulálnak, de

\footnotetext{
71 Például 개똥이 kaettongi „kutyakaki”, 쇠똥이 soettongi „tehénlepény”, 말똥이 malttongi „lócitrom” stb. (Kim-Lee 2003: 146-147.)

72 Pae 1981: 107-109.

73 Kim-Lee 2003: 138-143.
} 
tartózkodnak természetesen az alkoholtól és a nyers húsok fogyasztásától, helyette inkább választják a különböző rostokban gazdag gabonával kevert rizst, az édesburgonyát, valamint a tejet. Napjainkban nagyon sok internetes portál és személyes blog is foglalkozik a terhes nők étrendjével. Ezek javasolják a zöld színü zöldségeket, a csonthéjasokat, meghatározott halfajtákat megfelelően elkészítve, a C-vitaminban gazdag táplálékot, viszont tiltják a koffeintartalmú italokat, az édességeket, a hidegnek tartott gyümölcsöket (például dinnyefélék), az ananászt, a szénsavas italokat, a gyömbért és a füszeres ételeket, ${ }^{74}$ de a húsfélékre nem térnek ki olyan részletességgel, mint a hagyományos szabályok.

A hínárleves népszerüsége továbbra is töretlen, olyannyira, hogy a kórházak szülészeti osztályain is ez a menü mindennap. A kórházi ellátás után hazatérő édesanyák is több héten keresztül otthon is folyamatosan ezt fogyasztják. Ugyanakkor óvatosnak kell lenni, mert újabb kutatások felhívják a figyelmet, hogy a hínárleves túlzott fogyasztása negatív következményekkel is járhat. Való igaz, hogy erősíti az immunrendszert, és pozitív hatásai vannak a vérkeringésre is, de magas jódtartalma pajzsmirigy-túlmüködéshez vezethet. Mivel a leves folyamatos fogyasztásával a napi ajánlott jódbevitel több százszorosa kerül a szervezetbe, az anyatejjel ez a csecsemőhöz is eljut. A statisztikák pedig azt tükrözik, hogy Dél-Koreában nagyon magas és folyamatosan növekszik a pajzsmirigyrák megjelenésének az aránya, a koreai nők esetében magasan az első helyen áll. ${ }^{75}$ Hasonlóan megmaradt a köztudatban a fogantatási álom is. Nem nehéz ezzel kapcsolatban információt szerezni, mert minden koreai tudja a saját születésével kapcsolatos álmot, vagy legalábbis a rokonságától hallott már ilyenről.

Az aktuális helyzet megfelelő feltérképezéséhez egy rövid kérdéssorral felmérést készítettem a régi tradíciókkal kapcsolatban. ${ }^{76} 26$ és 43 év közötti válaszadóim pár kivétellel a fővárosban vagy annak agglomerációjában élnek. Többségük 2 gyermeket nevel, de voltak a válaszadók között olyanok is, akik

\footnotetext{
Sŏ - Sŏ 2017.
}

75 Chu 2017.

76 A válaszadók egy online ürlapot töltöttek ki, amelyben célzottan olyan kérdések voltak, amelyek segítettek felmérni, hogy a régi szokások mennyire maradtak meg a modern életvitelben. A válaszadók eldöntendő kérdésekre válaszoltak a szokás megtartásával, illetve annak elhagyásával kapcsolatban, majd kifejthették gondolataikat az indoklásrészben. A felmérés teret hagyott a személyes tapasztalatok és további gondolatok, meglátások kifejezésének is. A kis számú kitöltő válasza azonban nem elegendő reprezentatív következtetések levonásához. 
még a gyermekvállalás előtt állnak. A fogantatási álmot mindenki ismerte, és több mint fele válaszolta azt, hogy álmodott is a terhessége korai szakaszában. Kivétel nélkül fontosnak tartják a terhesség ideje alatti magzati nevelést, és hogy az édesanyának oda kell figyelnie mindenre, amit tesz. A tilalmakra vonatkozóan azonban már rövidebb válaszok érkeztek. A válaszadók fele nem tudott ilyet példának hozni, másik fele pedig inkább a modern korhoz igazodva a cigaretta és az alkohol kerülését, a sport csökkentését és a test melegen tartását említették. A szalmafüzért szintén a válaszadók fele ismerte csak, de a szokást a gyakorlatban nem tartották meg. Néhányan csak hallottak róla, de pontosan nem tudták volna definiálni. A hínárlevest mindegyikük fogyasztotta naponta több alkalommal, és pozitív hatásaival is teljesen tisztában vannak. A születés istenségének felállított asztalról a többség nem tudta, hogy micsoda, aki ismerte, azok közül egyetlen válaszadó tartotta meg a szokást. A placentával kapcsolatos régi hagyomány mindenki számára ismeretlen volt. Azt tudják, hogy manapság annak tárolása és/vagy felhasználása a kórház dolga, de több válaszadó egyszerüen annyit válaszolt, hogy ez a kérdés nem is érdekli. Arra a kérdésre viszont, hogy mit tud a régi születési szokásokról egyébként, különféle válaszok érkeztek. Többen is említették a 3, 7 és 21 napos szokásokat, továbbá hogy ezen időszakon belül nem fürödtek meg az anyák, és a hideget nagyon kerülték. A hínárleves is többször felmerült, illetve egy válaszadó kitért a régi társadalom fiúpreferenciájára is. Így az ő nagyszüleitől hallott dolgok alapján elmesélte, hogy akkoriban lánygyerek születésekor teljesen más hangulat szállta meg a családot, mint amikor fiú született.

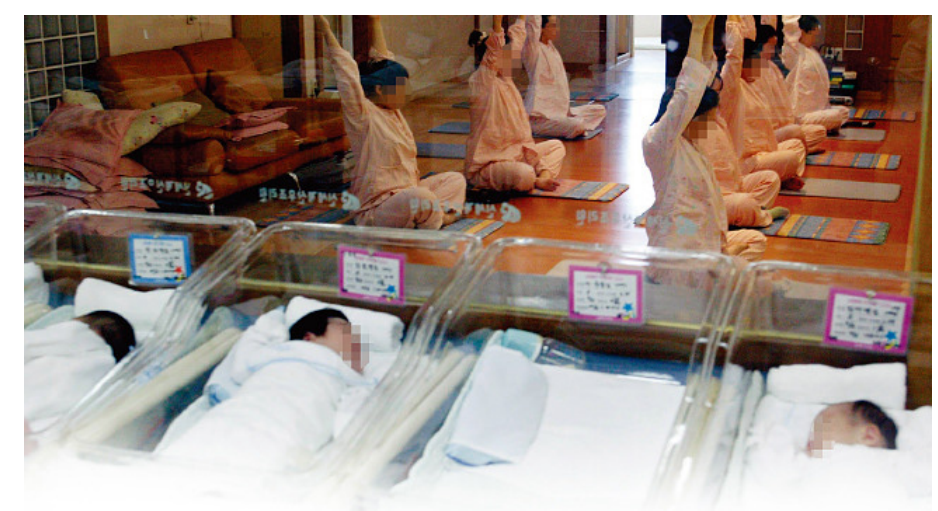

11. kép. 산후조리원 Szülés utáni gondozóklinika 
Utolsó kérdéseim pedig a teljesen aktuális, XXI. századi gyakorlatra vonatkoztak. Ennek elsősorban az volt a célja, hogy még láthatóbbá váljék a kontraszt a XXI. század első évtizedeiben végzett gyakorlat és XX. század eleji általános szokások között. A válaszok alapján kaphatunk összetettebb képet arról, hogy a nagymértékủ változásokat milyen okok válthatták ki. A válaszadók fele szülés után szülészeti gondozóklinikán (sanhujoriwŏn 산후조리원, 11. kép) regenerálódott, másik fele pedig otthon. Az otthon gyógyuló édesanyák közül többen pár hétre szülés utáni gondozónőt (sanhudoumi 산후도우미) alkalmaztak. Mivel az urbanizáció és a nagy távolságok miatt nem mindig megoldható, hogy valamelyik nagymama rendszeresen látogassa a családot, ezekre a szolgáltatásokra támaszkodnak családi kisegítés helyett. A gyerekvállalás azonban nem kis anyagi terhet is jelent a házaspár számára a modern társadalomban. A megkérdezettek közül többen összegekkel is pontosították válaszukat. A gyermek születéséig az azzal kapcsolatos költségek összesen 400 ezer forint körüli összeget jelentenek. Ha ezen kívül valaki konkrétan a gondozóklinikát választja az otthoni regenerálódás helyett, az még további ugyanekkora mértékủ kiadást jelent - a régi időkben sem volt nyilván költség nélküli egy gyermek vállalása, de nem jelentett aggodalomra okot adó terhet. Az egyik válaszadó elárulta, hogy csak a gyermek megszületéséig kiadott költség a férje kéthavi keresetét vitte el. A jövőbeli tervekkel kapcsolatos válaszok tükrözték a családok félelmeit. Az egygyerekesek fontolóra veszik a második gyermek vállalását is, mert fontosnak tartják a testvérkapcsolatot, ugyanakkor elrettentő lehet a gyermekvállalás hatalmas költsége. Vannak, akik emiatt az egy gyermek felnevelése mellett döntenek. Kettőnél több gyermek vállalását senki nem említette. A kérdéssor végén feltettem egy nyitott kérdést is, amellyel kiegészítő információk vagy egyéni vélemények hozzáadására szerettem volna lehetőséget adni. Egyik válaszadó rámutatott, hogy a szülés utáni hosszú gondozás eléggé Korea-specifikus gyakorlat, különösen a nyugatival összehasonlítva, de számukra ez biztonságot jelent, és mivel genetikailag más adottságokkal rendelkeznek, a koreai nők testét valószínüleg jobban megterheli a gyermek világra hozatala. A szülés után szülészeti gondozóklinikák egyik nagy előnyét is hangsúlyozták, miszerint ott az édesanyák között ismeretségek köttetnek, amelyeket a hazatérés után is megtartanak, így kapcsolati háló alakulhat ki olyan nők között, akiknek egyidősek a gyermekeik. ${ }^{77}$

77 A kapcsolati háló a koreai társadalom egyik alappillérének is tekinthető, akár a munka világában, akár az oktatás, szabadidő, gyermeknevelés stb. területén. 
Egy válaszadó nehezményezte, hogy a mai világban már a távol-keleti országokban is egyre általánosabbá válik, hogy a férj és a feleség is pénzkereső (matpǒri pubu 맞벌이 부부), mégis a gyermeknevelés és a háztartás terhe még mindig csak a feleség vállát nyomja. Szeretnék, ha lassan kialakulna az a felfogás a koreai férfiakban is, hogy az apaság és a háztartásban való részvétel nem csökkenti a férfiasságukat (namsŏngdaum 남성다움), és jobban részt vennének benne. Valamint előkerült az egyke gyerek elkényeztetésének a problémája is. Senkit nem ítélnek el, ha anyagi megfontolásból amellett dönt, hogy nem vállal egynél több gyermeket, de ennek nem lenne szabad azt eredményeznie, hogy azt az egy gyermeket túlzott gondozással torz személyiséggé nevelik. Oda kellene figyelni arra is, hogy ne csak a szülö-gyerek kapcsolat hangsúlyozódjon ilyen helyzetben, hanem kiegyensúlyozott legyen a viszony. Esetleg ezzel kapcsolatos oktatásra vagy tanácsadásra még igény is lehet.

A tanulmány által felvetett kérdések, főleg a XXI. századra vonatkozó bekezdés gondolatai még további bővebb kutatás részei is lehetnek, hiszen a tanulmány kereteiből kimaradt második világháború utáni családtervezés, az orvostudomány fejlődésének lépései, a fiúpreferencia lassú eltünése, a délkoreai demográfiai változások, a házasság és a gyermekvállalás életkorának kitolódása, valamint a mesterséges megtermékenyítés témái még kiegészíthetnék az elmúlt évtizedekre vonatkozó megállapításokat. Ugyanakkor a dolgozat célja főleg a XX. század elejéig tartó, hagyományosnak nevezhető évszázadok szokásait volt hivatott összegezni.

\section{Felhasznált másodlagos szakirodalom}

Birtalan Ágnes 2002. „Some Common Phenomena in Korean and Inner Asian Ancient Religious Systems.” In: Birtalan Ágnes (ed.) Aspects of Korean Civilisation. (Korean Studies in Hungary I.) Budapest: Eötvös Loránd University, Department of Inner Asian Studies: $13-20$.

Chin Aera 진애라 2016. „Han chung chŏnt'ongsahoeŭi imshin'gŭmgi koch'al 한. 중 전통사회의 임신금기(姙娠禁忌) 고찰 [A koreai és kínai hagyományos társadalom terhességhez füződő tabuinak áttekintése]." Urimunhakyŏn'gu 우리文學研究 52: $121-158$. 
Han'gungminsoktaesajŏn 한국민속대사전 [Koreai Néprajzi Nagyenciklopédia]. Han'guksajŏnyŏn'gusa 한국사전연구사, 1998.

„Kija”, I. kötet, 213-215.

„Miyŏkkuk”, I. kötet, 567.

„Pison”, I. kötet, 718.

„Samshin”, II. kötet, 768-769.

„Sanshindanji”, II. kötet, 769.

„T'aegyo", II. kötet, 1437.

„T'aemong”, II. kötet, 1440-1441.

„T'aeshil”, II. kötet, 1442.

Hoppál Mihály 2005. Sámánok Eurázsiában. Budapest: Akadémiai Kiadó.

Kim Chihyŏn 김지현 - I Okhŭi 이옥희 2003. „Sansogŭi chisokkwa pyŏnhwa yŏn'gu 산속(産俗)의 지속과 변화 연구 [Kutatás a születési rítusok folytatódásáról és változásairól]." Honammunhwayŏn'gu 호남문화연구32·33/12: 133-180.

Kovács Ramóna 2016. „A koreai konfuciánus női szerepek a Csoszon Királyság elzárkózásának időszakában (17-19. század) és a korabeli kereszténység hatása.” In: Dr. Birtalan Ágnes (főszerk.), Csáki Nelli - Takó Ferenc (szerk.) Keleti kutatások. Tanulmányok az ELTE BTK Távol-keleti Intézet OTDK dolgozataiból. 2013-2015. Budapest: ELTE BTK Távol-keleti Intézet, 139-190.

Pae Tosik 배도식 1981. „Han'gugŭi sansok 한국의 産俗 [Korea születési rítusai].” Minjongmunhwa 민족문화 7/12: 78-110.

Papp Melinda 2011. „A korai gyermekkor rítusai Japánban és a hozzákapcsolódó hagyományos népi hitvilág." Távol-keleti Tanulmányok 2011/1-2: 227-248.

Papp Melinda 2018. „Tisztaság és tisztátalanság képzetei a japán népi kultúrában - A gyermekszületéshez kapcsolódó rítusok és tilalmak.” In: Kósa Gábor - Vér Ádám (szerk.) Purum et immundum. Vallási képzetek tisztaságról és tisztátalanságról. Az Eötvös Loránd Tudományegyetem Bölcsészettudományi Karán 2016. október 14-15-én tartott vallástudományi konferencia elöadásai. AГION Könyvek 4. Budapest: Eötvös Loránd Tudományegyetem Bölcsészettudományi Kar Vallástudományi Központ, 121-132.

P'yo Inchu 표인주 - Han Miok 한미옥 1997. „Ilsaengŭirye 일생의례 [Egy élet rítusai]." Namdominsokyŏn'gu 남도민속연구 4/2: 169-179.

\section{Internetes források}

„Adŭl nak'irŭl pinŭn p'ungsong - kijasok 아들 낳기를 비는 풍속 - 기자속 [Szokások fiúgyerek-áldás érdekében]", Buddhista újság, 2008.06.18. http://www.ibulgyo.com/ news/articleView.html?idxno=88542 (utolsó letöltés: 2018.06 .11 .)

„Animizmus” Magyar Néprajzi Lexikon online. https://mek.oszk.hu/02100/02115/html /1-266.html (utolsó letöltés: 2019.11.10.)

„Ch'isŏnggija 한국민속대백과사전 [Áldozás gyermekáldásért]”, Folkency Encyclopaedia of Korean Culture, National Folk Museum of Korea. http://folkency.nfm.go.kr/kr/topic/ detail/479 (utolsó letöltés: 2019.11.24.) 
Ch'oe Chinyŏn 2015. „Nŭl kŭgose muri koyŏinnŭn sammaksa yŏgŭnsŏgŭi pimirŭn” 최진연: 늘 그곳에 물이 고여있는 삼막사 여근석의 비밀은 [A Sammak kolostor szemérem alakú sziklájának titka], Dailian 데일리. 2015.03.14. http://www.dailian. co.kr/news/view/493856 (utolsó letöltés: 2018.06.11.)

Chu, Marian 2017. „Doctors suspect health risks in overeating of 'miyeokguk”, Korea Biomedical Review, 2017.06.13. http://www.koreabiomed.com/news/articleView. html?idxno=707 (utolsó letöltés: 2018.12.29.)

„Kija 기자 [Rítus a gyermekáldásért]”, Han'gungminsoktaebaekkwasajŏn 한국민속대 백과사전 Folkency Encyclopaedia of Korean Culture, National Folk Museum of Korea. http://folkency.nfm.go.kr/kr/topic/detail/1832 (utolsó letöltés: 2018.12.29.)

„Kŭmgi 금기 [Tabu]”, Han'gungminjongmunhwadaebaekkwasajŏn 한국민족문화대 백과사전 Encyclopedia of Korean Culture, Academy of Korean Studies. http://encykorea.aks.ac.kr/Contents/Item/E0007629 (utolsó letöltés: 2018.12.29.)

„Miyeok-guk (Korean Seaweed Soup) - Postpartum Recovery”, Bing's Natural Health. 2016.09.28. https://bingsnaturalhealth.com.au/recipe/miyeok-guk-korean-seaweedsoup-postpartum-recovery/ (utolsó letöltés: 2018.12.29.)

„Ŏjetpam kilmongi hokshi t'aemong? adŭl ttal allyŏjunŭn t'aemong kubunhagi” 어젯밤 길몽이 혹시 태몽? 아들 딸 알려주는 태몽 구분하기 [A tegnapi szerencsés álmom vajon fogantatási álom? Hogyan különböztessük meg a fiúra és lányra utaló álmokat], Mom's diary 맘스다이어리 http://we.moms.kr/74 (utolsó letöltés: 2018.06.11.)

„Pison 비손 [Imádkozás]”, Han'gungminjongmunhwadaebaekkwasajŏn 한국민족문화 대백과사전 Encyclopedia of Korean Culture, Academy of Korean Studies. http://encykorea.aks.ac.kr/Contents/SearchNavi?keyword=비손\&ridx=0\&tot=5 (utolsó letöltés: 2018.12.29.)

„Rite of passage” Encyclopaedia Britannica online. https://www.britannica.com/topic/ rite-of-passage (utolsó letöltés: 2018.12.29.)

„Samshin 삼신 [Samshin]”, Han'gungminsoktaebaekkwasajŏn 한국민속대백과사전, Folkency Encyclopedia of Korean Culture. http://folkency.nfm.go.kr/kr/topic/ detail/2290 (utolsó letöltés: 2018.12.29.)

„Sanmowa shinsaengarŭl wihan yŏja ŭiryoin sanp'awa chosanwŏn 산모와 신생아를 위한 여자 의료인 산파와 조산원 [A szülőanyáért és a csecsemőért dolgozó női orvos, a bába és a szülész nővér]". 국립국어원 쉼표, 마침표, Shwimp'yo, mach'imp'yo. http://news. korean.go.kr/index.jsp?control=page\&part=view\&idx=8762 (utolsó letöltés: 2018.12.29.)

„Sanp'a 산파 [Bába]”, Han'gungminsoktaebaekkwasajön 한국민속대백과사전, Folkency Encyclopaedia of Korean Culture, National Folk Museum of Korea. http://folkency. $\mathrm{nfm} . \mathrm{go} . \mathrm{kr} / \mathrm{kr} /$ topic/detail/209 (utolsó letöltés: 2018.12.29.)

„Soji 소지 [Soji papír]”, Han'gungminjongmunhwadaebaekkwasajŏn 한국민족문화대 백과사전 Encyclopedia of Korean Culture, Academy of Korean Studies. http://encykorea.aks.ac.kr/Contents/Item/E0030283 (utolsó letöltés: 2018.12.29.)

Son Hyŏnhŭi 손현희 2007. „T'aeshil? kŭge mwŏnde? 태실? 그게 뭔 데? [Mi az a placentatemető?]", Omainyusŭ 오마이뉴스 Oh my news. 2007.11.29. http://www. ohmynews.com/NWS_Web/view/at_pg.aspx?CNTN_CD=A0000778686 (utolsó letöltés: 2018.12.29.) 
Sŏ Miyŏng 서미영 - Sŏ Yunam 서유남 2017. „P'ainaep'ŭrŭn mŏkŭmyŏn chŏltae an toenda? imshinbuga choshimhaeya hal ŭmshik" 파인애플은 먹으면 절대 안 된다? 임신부가 조심해야 할 음식 [Miért nem szabad ananászt enni? Ételek, amelyekkel a kismamának vigyáznia kell]. Tijit'ǔlchosŏnilbo 디지틀조선일보 Digital Chosun Ilbo. http://danmee.chosun.com/site/data/html_dir/2017/01/20/2017012001946.html (utolsó letöltés: 2018.12.29.)

„Sŏngju sejongdaewangja t'aeshil 성주 세종대왕자 태실 (星州 世宗大王子 胎室). [Sejong nagykirály placentatemetője Seongjuban]", Kukkamunhwayusanp'ot'ŏl 국가문화유산포털 Nemzeti kulturális kincs portál. http://www.heritage.go.kr/heri/ cul/culSelectDetail.do?VdkVgwKey=13,04440000,37\# (utolsó letöltés: 2018.12.29.)

„T'aegyoshin'gi 태교신기 [Új feljegyzések a méhen belüli nevelésről]”, Han'gungminsoktaebaekkwasajŏn 한국민속대백과사전 Folkency Encyclopedia of Korean Culture, National Folk Museum of Korea. http://folkency.nfm.go.kr/kr/ topic/detail/491 (utolsó letöltés: 2018.12.29.)

„T'aeshil 태실(胎室) [Placentatemető]”, Han'gungminjongmunhwadaebaekkwasajŏn 한국민족문화대백과사전 Encyclopedia of Korean Culture, Academy of Korean Studies. http://encykorea.aks.ac.kr/Contents/Item/E0058968 (utolsó letöltés: 2018.12.29.)

Wright, Michelle 2018. „What Are the Benefits of Seaweed Soup?” Livestrong.com https://www.livestrong.com/article/158110-what-are-the-benefits-of-seaweed-soup/ (utolsó letöltés: 2018.12.29.)

\section{Képek forrásai:}

1. kép: Női és férfi nemi szerv alakú szikla http://www.dailian.co.kr/news/view/493856 (utolsó megtekintés: 2018.12.29.)

2. kép: Női nemi szervre hasonlító szikla a Sammak buddhista kolostorban http://www. dailian.co.kr/news/view/493856 (utolsó megtekintés: 2018.12.29.)

3. kép: A fa kiházasítása http://m.ohmynews.com/NWS_Web/Mobile/img_pg.aspx? CNTN_CD=IA000590793\&atcd=A0000395512 (Utolsó megtekintés: 2018.12.31.)

4. kép: Imádság a gyermekáldás érdekében http://folkency.nfm.go.kr/kr/topic/detail/ 1832 (utolsó megtekintés: 2018.12.29.)

5. kép: Áldozati asztal a születés istenségének http://folkency.nfm.go.kr/kr/dic/5/ picture/4745 (utolsó megtekintés: 2018.12.31.)

6. kép: Áldozati asztal a születés istenségének http://www.yeoju.go.kr/history/jsp/ Common/Image_View.jsp?Num $=1605 \& V_{-}$Type $=A \& T$ Type $=A$ (utolsó megtekintés: 2018.12.31.)

7. kép: Szalmafüzér https://m.blog.naver.com/PostView.nhn?blogId=zallham\&logNo= 220791771566\&proxyReferer=https\%3A\%2F\%2Fwww.google.com\%2F (utolsó megtekintés: 2018.12.31.)

8. kép: Kerámiaedény a placenta elhelyezéséhez http://inews.ewha.ac.kr/news/article View.html?idxno=19319 (utolsó megtekintés: 2018.12.31.) 
9. kép: Sejong király leszármazottainak „,placentatemetője” http://www.ohmynews. com/NWS_Web/view/at_pg.aspx?CNTN_CD=A0000778686 (utolsó megtekintés: 2018.12.31.)

10. kép: Hínárleves http://shop.biumfood.com/detail2.php?item=452 (utolsó megtekintés: 2018.12 .31$.

11. kép: Szülés utáni gondozó klinika http://weekly.donga.com/List/3/all/11/531971/1 (utolsó megtekintés: 2018.12.31.] 